\title{
Analysis of Fibrous Compounds Using a Pressurized and Non-pressurized Conditions
}

\author{
Edgard Gonçalves Malaguez \\ Federal University of Pelotas (UFPel), Brazil \\ Andressa Tellechea Rodrigues \\ São Paulo State University (UNESP), Brazil \\ Kelli Flores Garcez \\ Federal Technological University of Paraná, Brazil
}

Gabriela Ceratti Hoch

Federal University of Pampa, Uruguaiana (UNIPAMPA), Brazil

Ana Paula Schmidt

Federal University of Pelotas (UFPEL), Brazil

Francisco Augusto Burkert Del Pino

Federal University of Pelotas (UFPEL), Brazil

Deise Dalazen Castagnara

Federal University of Pampa, Uruguaiana (UNIPAMPA), Brazil

Received: Aug. 27, 2020

doi:10.5296/jas.v8i4.17591
Accepted: Oct. 11, 2020 Published: Nov. 4, 2020

URL: https://doi.org/10.5296/jas.v8i4.17591 


\section{Abstract}

Neutral detergent fiber (NDF) and acid detergent fiber (ADF) contents were evaluated in pressurized and unpressurized conditions using samples of roughage and concentrates. In summary, the samples were dried, processed in a knife mill, weighed in nonwoven bags $\left(100 \mathrm{~g} / \mathrm{m}^{2}\right)$, placed in a container and treated with neutral or acid detergents. Extractions of $\mathrm{NDF}$ and ADF content were carried out in a non-pressurized condition at temperature of $100^{\circ} \mathrm{C}$ for $60 \mathrm{~min}$ and in pressurized condition using different temperatures of 100 and $110^{\circ} \mathrm{C}$ for 60min. Results of the different temperatures using the pressurized procedure were compared to those obtained with the pressurized through the linear regression analysis. The method with the temperature $110^{\circ} \mathrm{C}$ for $60 \mathrm{~min}$ had a high level of agreement. Was not observed a bias potential of proportion $(\mathrm{P}>0.05)$. There was not a systematic inclination of the methods to overestimate or underestimate errors. This methodology can be carried out with roughage and concentrate feedstuffs simultaneously.

Keywords: acid detergent fiber, autoclave, feedstuffs, neutral detergent fiber, temperature

\section{Introduction}

The concentration of structural carbohydrates has been used to determine the nutritional and digestible quality of food, as well as being a predictor in mathematical models to estimate energy. Since 1960s the analytical methods to determine fiber content have been used and improved by researchers. The fiber detergent analysis system was initially proposed by Van Soest in 1963 to determine neutral detergent fiber (NDF) and acid detergent fiber (ADF). Initially, the proposed $w$ to apply this methodology in forage, however it can be extended to analyze concentrated foods. Is well know that starch can contaminate samples, causing an overestimation of fiber values (Van Soest et al., 1991). Thus, the method to determine NDF and ADF has been improved to reduce the amounts of starch by using $\alpha$-amylase, sodium sulfite, or 8M urea solution (Van Soest et al., 1991). Other adaptations have been proposed as an alternative to the original test, including an application of the filter bag procedure and a replacement of the conventional digester such as the use of pressurized equipment, e.g., an autoclave. (Pell and Schofield, 1993; Deschamps, 1999; Ferreira and Mertens, 2007; Senger et al., 2008).

The technique to determine NDF and ADF requires: (a) specialized equipment, which is very expensive and usually is not available in all laboratories, there may still be the formation of air bubbles inside the bags, at the time of the detergent boiling, which compromises its contact with the sample reducing the extraction efficiency of the non-fibrous components of the food (Gomes et al., 2011), or (b) requires pressurized equipment or an autoclave, which is more common in laboratories. According to Senger et al. (2008), the use of filter bags and autoclave treatment for the analysis of NDF or ADF results in a more practical and rapid test when compared with the conventional method using Gooch crucibles. In addition, it can be cheaper than using the ANKOM ${ }^{\circledR}$ fiber analyzer. However, there is no agreement about treatment duration and temperature described in literature.

The objective of this study was to test the accuracy when using pressurized equipment for the 
analysis NDF and ADF by means of evaluating two temperatures in a pressurized environment and comparing them to the non-pressurized equipment (fiber analyzer) operated at a temperature recommended by the manufacturer.

\section{Method and Methods}

\subsection{Food Sampling and Location}

The experiment was performed at the Laboratory of Forage and Animal Nutrition at the Federal University of Pampa - Uruguaiana Campus/ RS. For this study, were used different samples from roughage and concentrate food to determine NDF ( $\mathrm{n}=19$ samples) and ADF ( $\mathrm{n}=13$ samples). The samples used in this study were: Avena sativa L. (oats, oats with husks and oats bran), Lolium multiflorum L. (Italian ryegrass), Pennisetum purpureum Schum (elephant grass, BRS Kurumi), Glycine max L. (soybean husks, crushed soybean, soybean plant, soybean meal, and soybean pie), Medicago sativa L. (alfalfa hay), native grass, Manihot esculenta (cassava silage and cassava root silage), Olea europaea (olive silage), Sorghum bicolor (sorghum), Zea mays L. (maize), Cynodon spp. (Tifton 68 e Tifton 85), Oryza sativa (rice bran, rice bran with husks, and broken rice), Zea mays L. (corn bran, wet corn grain, and ground corn), Helianthus annuus L. (sunflower and sunflower seed) (Table 1). Additional information about samples and fiber content (NDF and ADF) can be found in Table 1.

Table 1. Neutral (NDF) and acid (ADF) detergent fiber concentrations ( $\mathrm{g} / \mathrm{kg}$ dry matter) in experimental feedstuffs

\begin{tabular}{lccc}
\hline \multirow{2}{*}{ Feedstuff } & \multicolumn{3}{c}{ NDF } \\
\cline { 2 - 4 } & Not Pressurized & Pressurized at $100^{\circ} \mathrm{C}$ & Pressurized at $110^{\circ} \mathrm{C}$ \\
\hline White oats w/ husks I & $312 . .82$ & 325.80 & 250.23 \\
Oats III & $309 . .93$ & 326.23 & 252.88 \\
Oats bran & 321.90 & 292.03 & 276.40 \\
Ryegrass & 330.35 & 385.38 & 365.85 \\
Elephant grass Kurumi & 424.78 & 454.37 & 454.87 \\
Elephant grass dwarf & 446.40 & 454.28 & 365.40 \\
Elephant grass common & 413.20 & 469.15 & 441.92 \\
Soybean bran & 452.02 & 481.48 & 441.23 \\
Alfalfa hay & 467.97 & 500.03 & 482.17 \\
Native grass & 460.95 & 488.20 & 483.23 \\
Cassava silage & 404.20 & 424.42 & 380.22 \\
Olive silage & 302.22 & 341.80 & 341.37 \\
Soybean silage & 286.53 & 335.47 & 306.12 \\
Soybean plant & 393.93 & 429.52 & 409.95 \\
Sorghum plant & 433.80 & 468.78 & 466.05 \\
Teosinto & 377.33 & 397.28 & 389.48 \\
Tifton 68 & 459.55 & 492.52 & 505.25 \\
Tífton 85 & 462.66 & 498.95 & 483.73 \\
Soybean pie & 184.93 & 219.22 & 221.92 \\
\hline
\end{tabular}




\begin{tabular}{lccc} 
& \multicolumn{3}{c}{ ADF } \\
\hline Rice bran III & 171.58 & 171.85 & 145.70 \\
Rice bran w/husks II & 329.62 & 337.77 & 408.18 \\
Rice bran w/husks IV & 267.15 & 289.97 & 292.85 \\
Rice bran w/husks I & 226.70 & 236.87 & 236.52 \\
Corn bran II & 172.30 & 168.47 & 138.10 \\
Corn bran III & 106.47 & 129.23 & 130.58 \\
Soybean bran I & 128.35 & 142.00 & 81.33 \\
Sunflower II & 236.63 & 311.75 & 284.48 \\
Sunflower seed & 322.58 & 321.83 & 298.52 \\
Ground corn & 87.07 & 75.17 & 81.95 \\
Wet corn grain & 43.15 & 46.53 & 56.43 \\
Broken rice & 40.63 & 38.82 & 45.70 \\
Cassava root silage & 334.75 & 309.90 & 290.28 \\
\hline
\end{tabular}

Averages in $\mathrm{g} / \mathrm{NDF}$ and $\mathrm{ADF}$

\subsection{Fiber Analysis in Pressurized and Non-pressurized Conditions}

The samples used in this study were pre-dried in an oven with forced ventilation at $60^{\circ} \mathrm{C}$ for 72 hours and processed in a knife mill using a sieve with a porosity of $1 \mathrm{~mm}$. To carry out the analyses, nonwoven bags $\left(100 \mathrm{~g} / \mathrm{m}^{2}\right)$ were made, with approximately $25 \mathrm{~cm}^{2}$, heat sealed, and dried in the oven for 12 hours at temperature of $105^{\circ} \mathrm{C}$. After this procedure, the bags were weighed on an analytical balance and properly labeled. The samples were placed in the nonwoven bags, respecting the ratio of $20 \mathrm{mg}$ of dry matter per $\mathrm{cm}^{2}$ (Nocek, 1997).

The extraction of the detergent fiber was carried out in triplicate for each sample and both were arranged in a device with a pressurized and non-pressurized condition, following the detergent to sample ratio of approximately $100 \mathrm{ml} / \mathrm{g}$. A repetition of the all analytical execution was performed. For the concentrated samples, $8 \mathrm{M}$ urea and heat-stable $\alpha$-amylase were used (Termamyl 120L, Novozymes Latin América ltda.) To substantially reduce the amounts of starch, samples were submerged in a 1L beaker for 4 hours (VAN SOEST et al., 1991). To assess the fiber content in neutral detergent (NDF) and acid detergent (ADF), the detergent was prepared according to the recommendations of AOAC 2002.04; MERTENS, 2002 .

To determine NDF and ADF in a non-pressurized condition, an equipment model TE-149, manufactured by Tecnal ${ }^{\circledR}$, with a capacity of 30 tests separated into 10 perforated discs, was used. The foods were separated into concentrates foods and roughage and, subjected to a temperature of $100{ }^{\circ} \mathrm{C}$ for 60 minutes. After the procedure, the bags were washed sequentially, at least three times, with hot distilled water and soaked with acetone to remove the remaining detergent. Bags were dried in an oven with forced ventilation at $60^{\circ} \mathrm{C}$ for $24 \mathrm{~h}$. Subsequently, bags were dried again in an unventilated oven at $105^{\circ} \mathrm{C}$ for $2 \mathrm{~h}$. Then, the bags were placed in a desiccator until they reached room temperature and afterwards, weighed in a precision analytical balance 
To determine the NDF and ADF in a pressurized condition, model AV 18L equipment, manufactured by Phoeniz luferco, was used. The samples were placed in a Becker containing a solution of neutral or acid detergent. The Becker was properly sealed to prevent the entry of steam, and placed in a vertical autoclave for 60 minutes. This procedure was tested using two diferent temperatures: $100^{\circ} \mathrm{C}$ with pressure at $0 \mathrm{Kgf} / \mathrm{cm}^{2}$ and $110^{\circ} \mathrm{C} 0.33 \mathrm{Kgf} / \mathrm{cm}^{2}$. As in the previous method, the samples were also separated into roughage foods and concentrated. After treatment, the bottles were removed from the autoclave and the bags followed the same procedure describe previously for non-pressurized condition.

\subsection{Statistical Analysis}

The data were analyzed using the IBM SPSS Statistics software version 20.0. Shapiro - Wilk test was used to verify the normality of the data and Levene's test was used to check the homogeneity of variances. To assess whether there are differences between the variables, where the hypothesis of bias being zero or not was tested by the two-tailed t test, where there is agreement by $\mathrm{P}>0.05$. A simple linear regression equation was performed for the values obtained in a pressurized environment (Y) over the values obtained in a non-pressurized environment $(\mathrm{X})$. the statistical evaluation being conducted under the following assumptions: $\mathrm{H} 0: \beta 0=0$, and $\beta 1=1$; vs. Ha: not $\mathrm{H} 0$, where the regression slope deviation of 1 was assessed using a two-tailed t-test. For the case of non-acceptance of the null hypothesis, it was concluded that the extraction environments are different.

\section{Results}

The difference in NDF and ADF values was evaluated between the non-pressurized environment and the two temperatures in a pressurized environment (Table 2). In the NDF analysis, we observed a significant difference between the pressurized at $100{ }^{\circ} \mathrm{C}$ and nonpressurized environments $(\mathrm{P}<0.05)$, and there was an agreement $(\mathrm{p}$ - value $=0.59)$ between the pressurized at $110{ }^{\circ} \mathrm{C}$ and non-pressurized environments. In the ADF analysis, there was an agreement between the non-pressurized environment and both pressurized environments at $100{ }^{\circ} \mathrm{C}(\mathrm{p}$-value $=0.31)$ and $110{ }^{\circ} \mathrm{C}(\mathrm{p}$-value $=0.87)$.

Table 2. The analysis of the difference between pressurized and non-pressurized environments in the determination of neutral detergent fiber (NDF) and acid detergent fiber (ADF) at different temperatures

\begin{tabular}{|c|c|c|c|c|c|}
\hline \multirow[b]{2}{*}{ Difference } & \multirow{2}{*}{$\begin{array}{c}\text { Average } \\
\text { Bias }(\mathrm{g} / \mathrm{kg} \\
\text { dry matter) }\end{array}$} & \multirow[b]{2}{*}{ SEM } & \multirow[b]{2}{*}{ P- Value ${ }^{2}$} & \multicolumn{2}{|c|}{ Regression coefficient } \\
\hline & & & & $\beta 1^{3}$ & P-value ${ }^{4}$ \\
\hline \multicolumn{6}{|l|}{ NDF } \\
\hline Pressurized at $100^{\circ} \mathrm{C}$ - Not Pressurized & 28.39 & 4.17 & 0.01 & -0.032 & 0.547 \\
\hline $\begin{array}{l}\text { Pressurized at } 110^{\circ} \mathrm{C}-\text { Not Pressurized } \\
\text { ADF }\end{array}$ & 3.83 & 7.11 & 0.59 & -0.124 & 0.164 \\
\hline Pressurized at $100^{\circ} \mathrm{C}$ - Not Pressurized & 8.70 & 8.36 & 0.31 & 0.081 & 0.966 \\
\hline Pressurized at $110^{\circ} \mathrm{C}$ - Not Pressurized & 1.81 & 11.02 & 0.87 & -0.105 & 0.307 \\
\hline
\end{tabular}

SEM: standard error mean. ${ }^{1}$ According to the Student's $t$ test. ${ }^{2} \beta 1$ refers to the slope of the 
linear regression model $y=\beta 0+\beta 1 \mathrm{x} .{ }^{3} \mathrm{P}$-value of the predictor variable. NDF: neutral detergent fiber. ADF: acid detergent fiber.

The Table 2 also shows that a potential proportion bias was not observed $(\mathrm{P}<0.05)$ in either of the methods, i.e., there was no tendency for differences to be concentrated above or below the mean. Therefore, there was no systematic inclination of the methods to overestimate or underestimate errors. In the evaluation of potential proportion bias, it was observed that the methods had evenly distributed values $(\mathrm{P}<0.05)$. The linear regression analysis used the difference between methods as the dependent variable and the mean between the methods as the independent variable (Table 2).

The slope of the regression for both NDF and ADF did not differ from 1 ( $\mathrm{P}>0.05)$. The treatment with autoclave for NDF using the temperature of $110^{\circ} \mathrm{C}$ had the lowest coefficient of determination $\mathrm{R}^{2}=0.76$. For the $\mathrm{ADF}$ analysis, the highest coefficient of determination was for the temperature of $100{ }^{\circ} \mathrm{C}\left(\mathrm{R}^{2} 85 \%\right)$, however, for the temperature of 100 the $\mathrm{R}^{2}$ was $78 \%$ (Table 3).

Table 3. Relationship between neutral detergent fibre (NDF) concentrations ( $\mathrm{g} / \mathrm{kg}$ dry matter) in feed samples as analysed using not pressurized method (X) vs. pressurized (Y)

\begin{tabular}{lccc}
\hline Comparison & Regression & Slope S.E E $^{\mathrm{b}}$ & $R^{2}$ \\
\hline NDF & & & \\
Pressurized at $100^{\circ} \mathrm{C}-$ Not Pressurized & $Y=35.82+0.98 X$ & 0.054 & 0.90 \\
Pressurized at $110^{\circ} \mathrm{C}-$ Not Pressurized & $Y=12.04+0.97 X$ & 0.091 & 0.76 \\
ADF & & & \\
Pressurized at $100^{\circ} \mathrm{C}-$ Not Pressurized & $Y=24.00+0.91 X$ & 0.078 & 0.85 \\
Pressurized at $110^{\circ} \mathrm{C}-$ Not Pressurized & $Y=6.40+0.98 X$ & 0.105 & 0.78 \\
\hline
\end{tabular}

letter lowercase in $\mathrm{X}$ from the equation slope different from $1(\mathrm{P}<0.05)$. ${ }^{\mathrm{b}}$ Slope standard error where $n=38$ per treatment from NDE and $n=26$ per treatment from ADF.

\section{Discussion}

The use of pressurized equipment, such as autoclave allows for a greater number of samples to be processed simultaneously. Deschamps (1999), tested a similar approach that we used in this study, using filter bags and a pressurized equipment at $120{ }^{\circ} \mathrm{C}$ for 40 minutes. $\mathrm{He}$ described that autoclave had a greater productivity since it allows to use 120 samples per operation and generated considerable reagent savings. Cordeiro et al. (2007) compared the contents of NDF and ADF using the conventional method described by Pell and Schofield (1993), which uses digesting blocks/filter crucibles and a temperature of $105{ }^{\circ} \mathrm{C}$ for 60 minutes.

There was no difference ( $\mathrm{p}$-value $=0.12$ ) between the methods analyzed in this study, which proved the effectiveness to use pressurized equipment's to analyze fiber content, such as autoclave. To find an alternative procedure that was not different from the conventional method, Senger et al. (2008) evaluated different autoclave durations and temperatures in the $\mathrm{NDF}$ and ADF analyses. These authors concluded that the autoclave stated at $110{ }^{\circ} \mathrm{C}$ for 40 
minutes did not differ $(\mathrm{P}<0.05)$ from the conventional method, that uses a temperature at $105{ }^{\circ} \mathrm{C}$ for 60 minutes. Additionally, the analysis of forages and concentrates could be performed simultaneously. Gomes et al. (2011) utilized filter bags and compared a pressurized conditiosn with a non-pressurized conditions with effective extraction time of one hour at a temperature of $100^{\circ} \mathrm{C}$, observing differences between two conditions.

The results obtained in this experiment for NDF, showed to be sensitive to a temperature of $100{ }^{\circ} \mathrm{C}$. However, at a temperature of $110{ }^{\circ} \mathrm{C}$, the NDF proved to be accurate for treatment using non-pressurized equipment. In the FDA tests, all temperatures tested were using a non-pressurized method and were consistent with the non-pressurized physical condition. Although the coefficient of determination, it is lower, both for NDF and FDA, using a temperature of $110^{\circ} \mathrm{C}$, its use is recommended, as it is closer to the differences between the environments. According our findings we can recommend the use of pressurized equipment, such as the autoclave to determine fiber content. Other observations include: (a) the pressurization to avoid accumulation of gas in the bags, which can compromise the action of the detergent, and (b) the nitrogen content of the waste can be analyzed in a subsequent step by the Kjeldhal method (Senger et al., 2008; Gomes et al., 2011).

\section{Conclusions}

The analysis of fiber in neutral and acid detergent in pressurized condition at a temperature of $110{ }^{\circ} \mathrm{C}$ for $60 \mathrm{~min}$ was consistent with the non-pressurized method, just as roughage and concentrated foods can be performed simultaneously.

\section{References}

Cordeiro, C. F. A., Pereira, M. L. A., Mendonça, Almeida, P. J. P., Aguiar, L. V., \& Figueiredo, M. P. (2007). Intake and total digestibility of nutrients and milk production and composition in dairy cows fed with increasing crude protein levels in the diet with sugar cane and concentrates. Revista Brasileira de Zootecnia, 36, 2118-2126.

https://doi.org/10.1590/S1516-35982007000900023

Deschamps, F. C. (1999). Effects of growing periods on digestion and chemical composition of elephant grass cultivars tissues (Pennisetum purpureum Schumach.). Revista Brasileira de Zootecnia, 28, 1358-1369. https://doi.org/10.1590/S1516-35981999000600025

Ferreira, G., \& Mertens, D. R. (2007). Measuring detergent fibre and insoluble protein in corn silage using crucibles or filter bags. Animal Feed Science Technology, 133, 335-340. https://doi.org/10.1016/j.anifeedsci.2006.04.010

Gomes, D. I., Detmann, E., Valente, T. N. P., Valadares Filho, S. C., \& Queiroz, A. C. (2011). Laboratorial evaluation of fibrous compounds in feeds and cattle feces under different physical environments. Arquivos Brasileiros de Medicina Veterinariae Zootecnia, 63, 522-525. https://doi.org/10.1590/S0102-09352011000200038

IBM Corp. Released (2011). IBM SPSS Statistics for Windows, Version 20.0. Armonk, NY: IBM Corp.

Mertens, D. R. (2000). Gravimetric determination of amylase treated neutral detergent fiber in feeds with refluxing in beaker or crucibles: collaborative study. Journal of AOAC International, 85, 1217-1240. 


\section{Macrothink}

Nocek, J. E. (1997). In situ and other methods to estimate ruminal protein and energy digestibility: a review. In: Teixeira, J.C. (Ed.), Digestibilidade em ruminantes. FAEPE, Lavras, 197-240. http://doi.org/ 10.3168/jds.S0022-0302(88)79781-7.

Pell A. N., \& Schofield, P. (1993). Computerized monitoring of gas production to measure forage digestion in vitro. Journal of Dairy Science, 76, 1063-1073. https://doi.org/10.3168/jds.S0022-0302(93)77435-4

Senger, C. C. D., kozloski, G. V., sanchez, L. M. B., Mesquita, F. R., Alves, T. P., \& Castagnino, D. S. (2008). Evaluation of autoclave procedures for fibre analysis in forage and concentrate feedstuffs. Animal Feed Science Technology, 146, 169-174. https://doi.org/10.1016/j.anifeedsci.2007.12.008

Van Soest, P. J. (1963). Use of detergents in the analysis of fibrous feeds. A rapid method for the determination of fiber and lignin. Journal of AOAC International, 46, 829-835. https://doi.org/10.1093/jaoac/46.5.829

Van Soest, P. J., Robertson. J. B., \& Lewis, B. A. (1991). Methods foe dietary fiber, neutral detergent fiber, and non starch polysaccharides in relation to animal nutrition. Journal of Dairy Science, 74, 35-83. https://doi.org/10.3168/jds.S0022-0302(91)78551-2

\section{Copyright Disclaimer}

Copyright for this article is retained by the author(s), with first publication rights granted to the journal.

This is an open-access article distributed under the terms and conditions of the Creative Commons Attribution license (http://creativecommons.org/licenses/by/4.0/). 